Available online at http://iddtonline.info

RESEARCHARTICLE

\title{
A PRECISE RP-HPLC METHOD DEVELOPMENT FOR THE SIMULTANEOUS ESTIMATION OF DIAZEPAM AND PROPRANOLOL HYDROCHLORIDE IN TABLET DOSAGE FORM
}

\author{
Saravanan VS*, Nayeem Malik Shaik, \\ Dept of Pharmaceutical Analysis, The Erode College of pharmacy, Perundurai Main Road, Vallipurathanpalayam (po), \\ Veppampalayam, ERODE - 638112, Tamilnadu, INDIA \\ *Corresponding author e-mail: saravecp@yahoo.co.in, Contact no: +91-94438 38566
}

Received 03 August 2012; Review Completed 11 Sep 2012; Accepted 11 Sep 2012, Available online 15 Sep 2012

\begin{abstract}
:
A simple, precise, and accurate RP - HPLC method was developed and validated for the simultaneous estimation of Diazepam and Propranolol Hydrochloride in bulk and tablet dosage form. Isocratic elution at a flow rate of $1.0 \mathrm{~mL} / \mathrm{min}$ was employed on BDS Hypersil C18 (250 X 4.6 I.D., $5 \mu \mathrm{m}$ particle size) at ambient temperature. The mobile phase consisted of mixed buffer ( $0.02 \mathrm{M}$ potassium dihydrogen ortho phosphate and $0.003 \mathrm{M}$ dipotassium hydrogen phosphate, $\mathrm{pH}$ adjusted to 3.0 with ortho phosphoric acid) and acetonitrile (40:60v/v). The UV detection wavelength was $222 \mathrm{~nm}$ and $20 \mu \mathrm{L}$ of sample was injected. The retention times of Diazepam and Propranolol Hydrochloride were $2.031 \mathrm{~min}$ and $5.597 \mathrm{~min}$ respectively. The linearity was obtained in the range of $2-12 \mu \mathrm{g} / \mathrm{mL}$ for diazepam and $16-96 \mu \mathrm{g} / \mathrm{mL}$ for propranolol hydrochloride. The mean $\%$ recovery of diazepam and propranolol hydrochloride was found to be $99.92,99.94$ respectively. The \% RSD for precision and accuracy of the method was found to be less than $1 \%$. The method was validated as per the ICH guidelines. The method developed was found to be precise and accurate for the simultaneous estimation of diazepam and propranolol hydrochloride in tablet dosage forms.

Key words: Diazepam, Propranolol Hydrochloride, \%RSD, RP - HPLC, validation, simultaneous estimation.
\end{abstract}

\section{INTRODUCTION}

Propranolol hydrochloride is a sympatholytic, non selective beta blocker. Propranolol was indicated in the management of various conditions like hypertension, angina pectoris, tachyarrhythmia, and myocardial infarction and in management of anxiety Propranolol hydrochloride acts by competing with sympathomimetic neuro transmitters such as catecholamines for binding at beta (1) adrenergic receptors in the heart and inhibiting sympathetic stimulations. Chemically propranolol hydrochloride is (RS)-1-isopropyl amino-3-(1-napthyl oxy) propan-2-ol hydrochloride (Fig 1).<smiles>CC(C)NCC(O)COc1cccc2ccccc12</smiles>

$\mathrm{HCl}$

Figure 1: Structure of Propranolol Hydrochloride

Diazepam is a drug that comes under the class of benzodiazepines. Diazepam is indicated for the management of anxiety disorders or for the short term relief of symptoms of anxiety. It is also useful in the symptomatic relief of delirium, hallucination. Chemically diazepam is 7-chloro-1,3-dihydro-1-methyl-5-phenyl-1,4benzodiazepin-2-one (Fig2). Diazepam acts by binding to the $\mathrm{GABA}_{\mathrm{A}}$ receptors and cause an increased opening of chloride ion channels, and enhances the CNS depressant effect.

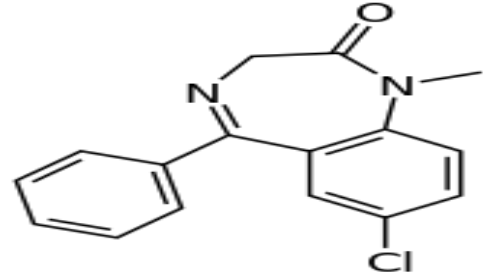

Figure 2: Structure of Diazepam

Literature survey suggests that few analytical methods have been reported for the estimation of diazepam and propranolol hydrochloride, individually and with other drugs by spectrophotometry ${ }^{1-2}$ and by liquid chromatography ${ }^{3-6}$ capillary electrophoresis ${ }^{7,}$ GC ${ }^{8}$, HPTLC ${ }^{9}$ The method developed shows short run time, with good resolution, theoretical plates and was found to be economical than the other research works. The aim of the present study is to develop a simple, precise, accurate, sensitive HPLC method for the estimation of diazepam and propranolol hydrochloride in tablet dosage form. The ${ }_{10}$ method was validated in compliance with ICH guidelines

\section{EXPERIMENTAL}

\section{Chemicals and reagents}

HPLC grade acetonotrile, water, from Merk pvt. Ltd. Potassium dihydrogen ortho phosphate, dipotassium ortho phosphate, ortho phosphoric acid, sodium hydroxide and hydrochloric acid of analytical grade were used. The standard samples of Diazepam and Propranolol hydrochloride were provided as a gift sample from 
Chandra labs. Hyderabad. Tablet formulation (Dizipax, Altius pharma) each tablet containing $2.5 \mathrm{mg}$ of Diazepam and $20 \mathrm{mg}$ of Propranolol hydrochloride.

\section{Instrumentation and analytical conditions}

The analysis was carried out by using Shimadzu HPLC system equipped with LC- 20 ATVP series pump, Rheodyne injector, and UV detector with Spinchrome software. Double beam UV- Visible spectrophotometer (Systronics), digital balance (Sartorious), vacuum pump (Gelman science), pH meter (Elico)

\section{Chromatographic conditions}

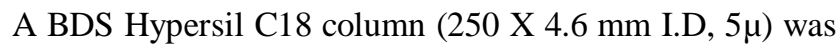
used for separation. The mobile phase consists of $0.02 \mathrm{M}$ potassium dihydrogen ortho phosphate, $0.003 \mathrm{M} \mathrm{di}$ potassium ortho phosphate and acetonotrile with $\mathrm{pH} 3.0$ adjusted with ortho phosphoric acid in a ratio of 40:60 v/v. The flow rate was delivered at $1.0 \mathrm{~mL} / \mathrm{min}$ with detection wavelength at $222 \mathrm{~nm}$. A $20 \mu \mathrm{L}$ was injected to the chromatographic system with ambient temperature.

\section{Stock and working standard solutions}

Stock solution was prepared by taking $20 \mathrm{mg}$ of Propranolol hydrochloride and $2.5 \mathrm{mg}$ of Diazepam in a 25 $\mathrm{mL}$ volumetric flask. Add $10 \mathrm{~mL}$ of mobile phase and sonicate for $5 \mathrm{~min}$ until the drugs were dissolved completely. Made the remaining volume with the mobile phase. Filter through the $0.45 \mu$ membrane filter. Calibration curve was plotted by taking six different concentrations from the stock solution ranging from $2-12$ $\mu \mathrm{g} / \mathrm{mL}$ for Diazepam and $16-96 \mu \mathrm{g} / \mathrm{mL}$ for Propranolol hydrochloride. All the six injections were injected into the chromatographic system and chromatograms were recorded.

\section{Assay procedure ${ }^{12}$}

Weigh 20 tablets and take average weight. The tablets were finely powdered and take an equivalent weight of 2.5 $\mathrm{mg}$ of Diazepam and $20 \mathrm{mg}$ of Propranolol hydrochloride into a $25 \mathrm{~mL}$ volumetric flask. Add about $10 \mathrm{~mL}$ of mobile phase and sonicate to dissolve completely, make up the remaining volume up to the mark with mobile phase. Filter through $0.45 \mu$ membrane filter. A $20 \mu \mathrm{L}$ solution was injected into the chromatographic system and peak area was measured.

Table 1: Assay Results

\begin{tabular}{|l|l|l|l|}
\hline Drug name & Label claim(mg) & Amount found(mg) & \% Amount Found \\
\hline Diazepam & 2.5 & 2.52 & 100.96 \\
\hline Propranolol hydrochloride & 20 & 19.99 & 99.95 \\
\hline
\end{tabular}

\section{Validation procedure}

The objective of the method validation is to demonstrate whether the method was suited for the intended purpose. The method was validated as per the ICH guidelines. The method was validated 11 for linearity, precision (repeatability, intermediate precision), accuracy, specificity, robustness, ruggedness, limit of detection, limit of quantification. A calibration graph was constructed by taking six different concentrations, ranging from 2 $12 \mu \mathrm{g} / \mathrm{mL}$ of diazepam and $16-96 \mu \mathrm{g} / \mathrm{mL}$ of propranolol hydrochloride. The peak area was calculated and calibration curve was constructed by taking peak area and concentration on both the axis. The linearity was evaluated by linear regression analysis. The precision studies were demonstrated by two parameters repeatability and intermediate precision. Repeatability was performed by injecting five replicated injections to the chromatographic system on the same day and calculated the \%RSD. The intermediate precision was performed by injecting five replicated injections at two consecutive days. From the peak area of the chromatograms, the \%RSD was calculated. The accuracy was determined by adding a known amount of the standard to the sample, and the percentage recovery was estimated. The robustness was determined by incorporating deliberate changes into the method conditions like the change in flow rate, change in wavelength. Ruggedness was performed by carrying out the proposed method with two different analysts.

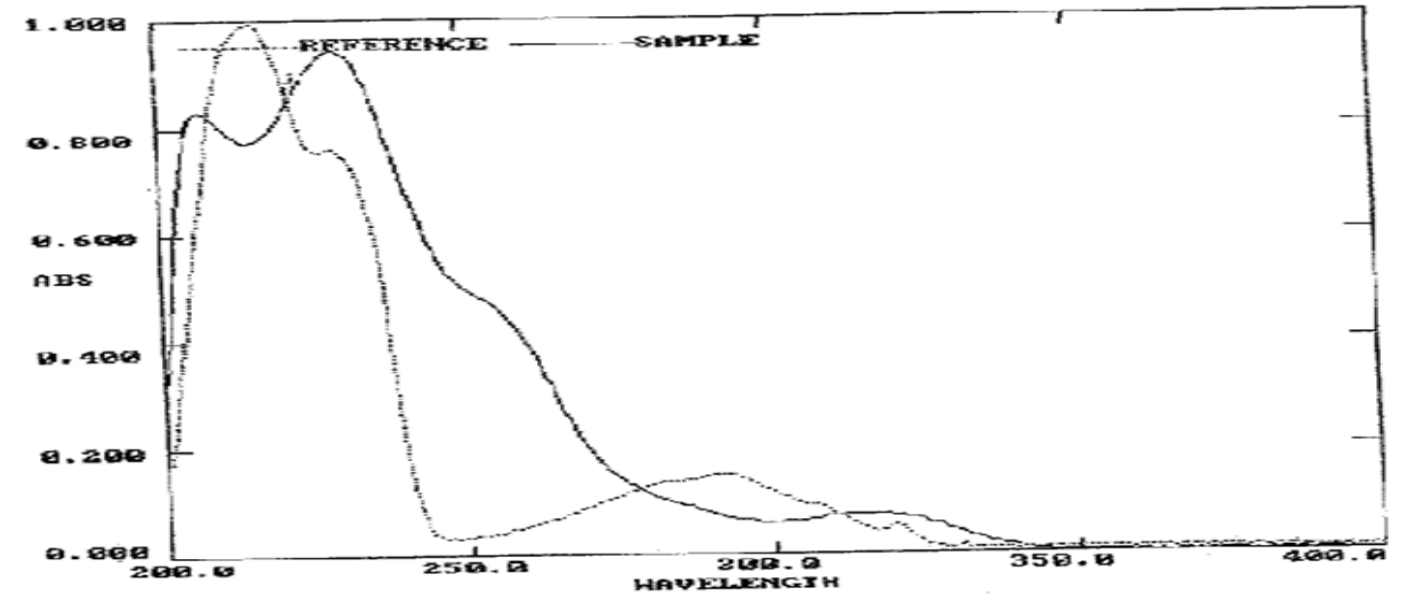

Figure 3: UV spectrum of Diazepam and Propranolol Hcl 


\section{RESULTS AND DISCUSSION}

\section{Selection of wavelength}

UV spectrum was obtained by preparing a solution by taking both diazepam and propranolol hydrochloride in the mobile phase and scanned between 200 to $400 \mathrm{~nm}$. Both the drugs show absorption maxima ( $\lambda \max )$ at $222 \mathrm{~nm}$. So it is selected as a detection wavelength.

\section{Development and optimization of the HPLC method:}

For getting an optimized chromatographic conditions a

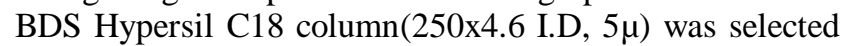
as a stationary phase and a mobile phase composition of mixed phosphate buffer (potassium dihydrogen phosphate and dipotassium ortho phosphate) and acetonitrile in the ratio of 40:60 v/v, $\mathrm{pH}$ adjusted to 3.0 with ortho phosphoric acid. This composition gives good resolution, asymmetry. The run time was found to be short, for diazepam it was 2.031 and for propranolol hydrochloride it was 5.597. The mobile phase composition was selected as the optimized chromatographic condition.

\section{METHOD VALIDATION}

\section{Linearity}

Linearity was performed by plotting a calibration graph by taking six concentrations in the range of $2-12 \mu \mathrm{g} / \mathrm{mL}$ for diazepam and $16-96 \mu \mathrm{g} / \mathrm{mL}$ for propranolol hydrochloride. The slope, intercept, correlation coefficient was found to be $26.01,11.87,0.999$ for diazepam and $4.328,11.54,0.999$ for propranolol hydrochloride. The standard deviation, intercept were found to be low. The data regarding the linearity was shown in the Table 2. Calibration curves of Diazepam and Propranolol hydrochloride were shown in fig: 4 and fig: 5

Table 2: Linearity Data

\begin{tabular}{|c|c|c|c|}
\hline Concentration & & Concentration & \\
\hline $\begin{array}{l}\text { Diazepam } \\
(\mu \mathrm{g} / \mathrm{ml})\end{array}$ & $\begin{array}{c}\text { Peak } \\
\text { Area }\end{array}$ & $\begin{array}{l}\text { Propranolol } \\
\text { hydrochloride } \\
(\mu \mathrm{g} / \mathrm{ml})\end{array}$ & $\begin{array}{l}\text { Peak } \\
\text { Area }\end{array}$ \\
\hline 2 & 62.048 & 16 & 78.539 \\
\hline 4 & 114.905 & 32 & 150.111 \\
\hline 6 & 172.473 & 48 & 224.168 \\
\hline 8 & 220.347 & 64 & 286.931 \\
\hline 10 & 271.55 & 80 & 357.496 \\
\hline 12 & 322.754 & 96 & 426.312 \\
\hline
\end{tabular}

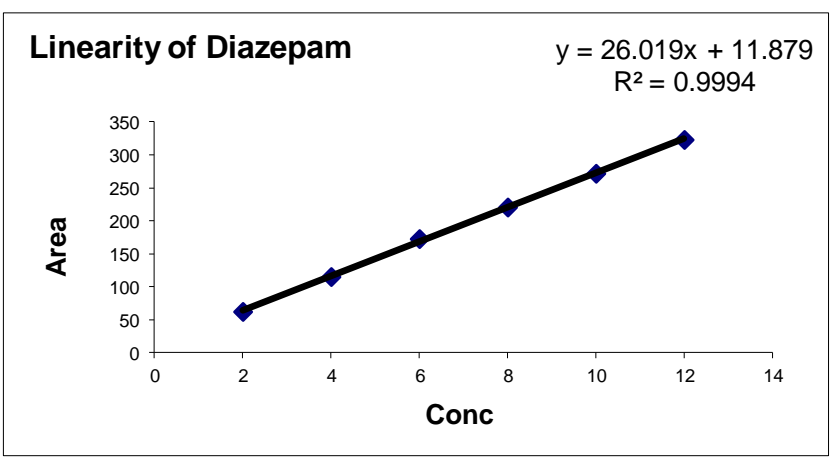

Figure 4: Calibration curve of Diazepam

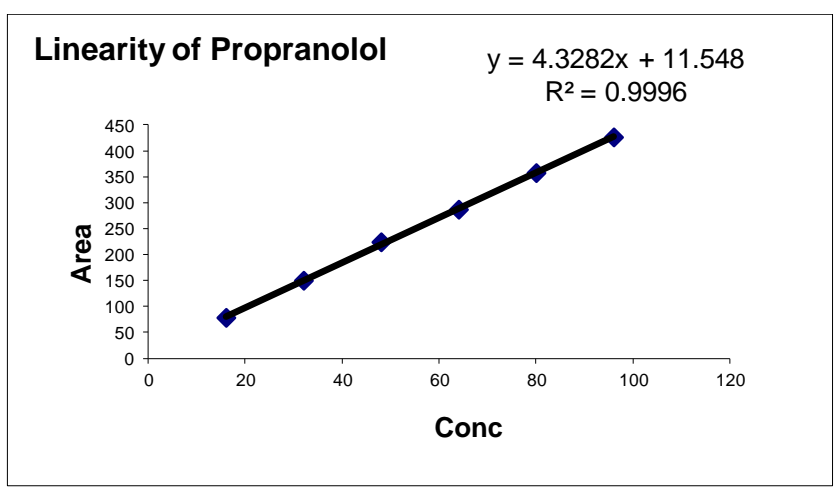

Figure 5: Calibration curve of Propranolol hydrochloride

\section{Precision}

Five replicated injections were performed into the HPLC system from the stock solution within the same day and different days. From the peak areas the \%RSD was calculated for repeatability and inter day precision. The $\%$ RSD was found to be less than 1 .

Table 3: Repeatability Data

\begin{tabular}{|c|l|l|}
\hline S. No & Area of Diazepam & $\begin{array}{l}\text { Area of Propranolol } \\
\text { hydrochloride }\end{array}$ \\
\hline 1. & 272.077 & 360.202 \\
\hline 2. & 271.895 & 360.309 \\
\hline 3. & 271.771 & 359.896 \\
\hline 4. & 273.904 & 361.776 \\
\hline 5. & 275.607 & 362.609 \\
\hline Mean & 273.0508 & 360.9584 \\
\hline S.D & 1.672 & 1.174 \\
\hline \%RSD & 0.61 & 0.33 \\
\hline
\end{tabular}

Table 4: Intermediate Precision

\begin{tabular}{|c|c|c|}
\hline S. No & Area of Diazepam & $\begin{array}{c}\text { Area of Propranolol } \\
\text { hydrochloride }\end{array}$ \\
\hline 1. & 276.01 & 362.998 \\
\hline 2. & 272.83 & 362.177 \\
\hline 3. & 272.63 & 362.312 \\
\hline 4. & 274.95 & 364.609 \\
\hline 5. & 273.81 & 366.127 \\
\hline Mean & 274.05 & 363.6446 \\
\hline S.D & 1.431 & 1.691164 \\
\hline \%RSD & 0.52 & 0.47 \\
\hline
\end{tabular}


Accuracy: Accuracy was expressed in terms of percentage recovery. Recovery studies were carried out by adding a standard drug to a fixed amount of sample at three different levels. Each injection was replicated for three times. From peak areas, the percentage recovery was calculated.

Table 5: Accuracy Data

\begin{tabular}{|c|c|c|c|c|}
\hline S.No & Drugs & Concentratios $(\mu \mathrm{g} / \mathrm{mL})$ & Average area & \% Recovery \\
\hline 1. & \multirow{3}{*}{ Diazepam } & $9 \mu \mathrm{g} / \mathrm{mL}$ & 246.868 & $99.97 \%$ \\
\hline 2. & & $11 \mu \mathrm{g} / \mathrm{mL}$ & 301.3023 & $99.83 \%$ \\
\hline 3. & & $13 \mu \mathrm{g} / \mathrm{mL}$ & 359.6953 & $99.96 \%$ \\
\hline 1. & \multirow{3}{*}{$\begin{array}{l}\text { Propranolol } \\
\text { hydrochloride }\end{array}$} & $72 \mu \mathrm{g} / \mathrm{mL}$ & 359.6953 & $99.90 \%$ \\
\hline 2. & & $88 \mu \mathrm{g} / \mathrm{mL}$ & 401.817 & $99.96 \%$ \\
\hline 3. & & $104 \mu \mathrm{g} / \mathrm{mL}$ & 474.9137 & $99.97 \%$ \\
\hline
\end{tabular}

\section{Limit of detection and Limit of quantification}

The limit of detection was performed by taking the slope and intercept values from the linearity studies. Limit of detection can be calculated by using a formula, LOD = $3.3 \times \mathrm{S} . \mathrm{D} / \sigma$. Where $\sigma=$ slope, S.D is standard deviation. The limit of quantification was determined by using the formula $\mathrm{LOQ}=10 \times \mathrm{S} . \mathrm{D} / \sigma$. The LOD was found to be $0.181 \mu \mathrm{g} / \mathrm{mL}$ for diazepam and $1.289 \mu \mathrm{g} / \mathrm{mL}$ for propranolol hydrochloride. The LOQ was found to be $0.55 \mu \mathrm{g} / \mathrm{mL}$ for diazepam and $3.907 \mu \mathrm{g} / \mathrm{mL}$ for propranolol hydrochloride.

\section{Robustness}

Deliberate changes were made to the method like change in wavelength by $\pm 2 \mathrm{~nm}$ and change in the flow rate by \pm $0.1 \mathrm{~mL}$. There was no marked change in the retention time and peak area.

Table 6: Robustness Data

\begin{tabular}{|c|c|c|c|}
\hline \multirow{2}{*}{ Parameters } & \multirow{2}{*}{ variation } & \multicolumn{2}{|c|}{ Retention time(min) } \\
\cline { 2 - 4 } & & Diazepam & Propranolol hydrochloride \\
\hline Flow rate $(\mathrm{mL})$ & 0.9 & 2.030 & 5.600 \\
& 1.1 & 2.036 & 5.590 \\
\cline { 2 - 4 } & 220 & 2.031 & 5.603 \\
\cline { 2 - 4 } & 224 & 2.043 & \\
\hline \multirow{2}{*}{ Wavelength $(\mathrm{nm})$} & &
\end{tabular}

\section{System suitability}

System suitability parameters were calculated, and the values were found to be within the limit. From the system

suitability parameters the method shows linearity, good resolution and symmetry

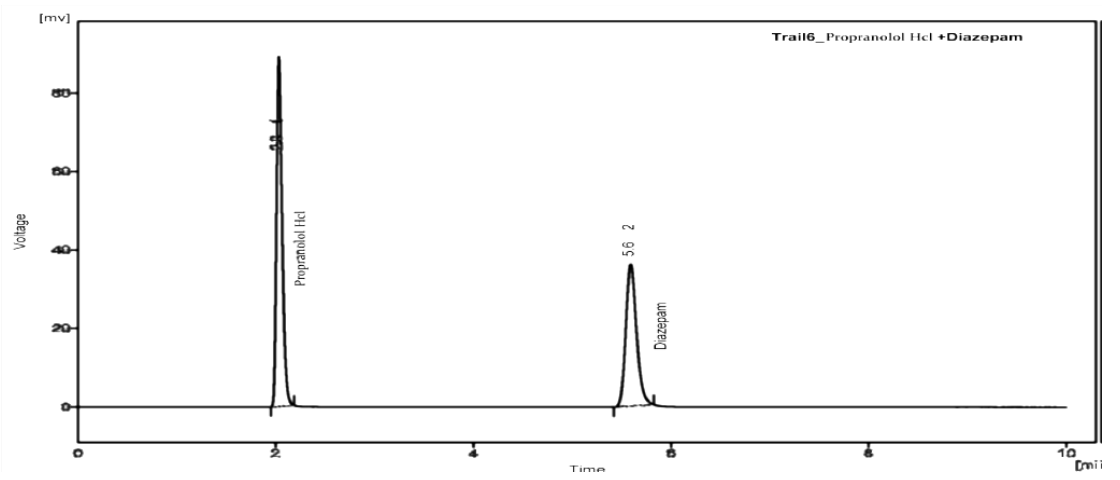

Figure 6: Optimized Chromatogram

Table 07: System suitability parameters

\begin{tabular}{|l|l|l|}
\hline Parameters & Diazepam & Propranolol hydrochloride \\
\hline Retention time $(\mathrm{min})$ & 2.031 & 5.597 \\
\hline Theoretical plates & 12779 & 5710 \\
\hline Asymmetric factor & 1.400 & 1.233 \\
\hline Resolution & 22.895 & $16-96$ \\
\hline Linearity $(\mu \mathrm{g} / \mathrm{mL})$ & $2-12$ & 0.999 \\
\hline Correlation coefficient $\left(\mathrm{R}^{2}\right)$ & 0.999 & 4.328 \\
\hline Slope $(\mathrm{m})$ & 26.01 & 11.54 \\
\hline Intercept $(\mathrm{c})$ & 11.87 & 1.289 \\
\hline Limit of detection $(\mu \mathrm{g} / \mathrm{mL})$ & 0.181 & 3.907 \\
\hline Limit of quantification $(\mu \mathrm{g} / \mathrm{mL})$ & 0.55 & \multicolumn{2}{|l}{} \\
\hline
\end{tabular}




\section{CONCLUSION}

A precise RP - HPLC method was developed for the simultaneous estimation of diazepam and propranolol hydrochloride. The shorter run time elutes both diazepam and propranolol hydrochloride with good resolution, and

\section{REFERENCES}

1. Debabrata, Ghosh., Dastidart, Biswanath, SA. "A comparative study of UV - spectrophotometric and first order UV - spectrophotometry methods for the estimation of diazepam in the presence of tween 20 and propylene glycols", AAPS Pharmscitech. 2009. 10(4), $1396-1400$.

2. Patel, Satish., A, Patel, Paresh., U, Patel, Natavarlal., J. "Development and validation of spectrophotometric method for the simultaneous estimation of diazepam and propranolol hydrochloride in combined dosage form", International Research Journal of Pharmacy. 2011.2(8), 119- 123.

3. P.Modamio, C.F.Lastra, O., Montejo, E.L.Marifio. "Development and validation of liquid chromatographic methods for the quantitation of propranolol, metoprolol, atenolol, bisoprolol", International J. Pharmaceutics. 1996. 130(1), 137- 140.

4. Mohammad, Reza., Rouini, Yalda, H., Ardakani, Kambiz, A., Moghaddam, F. Solatani "An improved HPLC method for rapid quantitation of diazepam and its metabolites in human plasma", Talanta. 2008. 75(3), 671-676.

5. Samia, M., El-Gizawy. "Simultaneous determination of diazepam, oxazepam, tenazepam, in spiked urine by HPLC", Analytical Letters. 2000. 33(4), $629-638$.

6. Tulja, Rani, G , Gowri, Shankar., D, P, Kadgapathi, Satyanarayana, B. "Development of an RP - HPLC Method for the Simultaneous Estimation of Propranolol hydrochloride symmetry. The method was validated as per the ICH guidelines and the method was found to be simple, precise, linear, accurate and robust enough

and Diazepam in combined Dosage forms", Indian Journal of Pharmaceutical Education and Research. 2011, 45(4), 296300.

7. Micke GA, Costa AC, Heller M, Barcellos M, Pioyezan M. "Development of fast capillary electrophoresis method for the determination of propranolol - total analysis time reduction strategies", J Pharmatogr A. 2009. 1216(45), 7957 - 7961.

8. Van, T., Vu, Fred, P., Abramson. "Quantitative Analysis of Propranolol and Metabolites by Gas chromatography and mass spectrometer computer Techniques", Biol. Mass Spectrom, 1978, 5(12), 686- 691.

9. Vishali, P., Michale, Avinash, T. Gatade, Dr. Ramesh T Sane. "Validated HPTLC content uniformity test for the determination of diazepam in tablet dosage forms", International Journal of Pharmaceutical Research and Development, 2011. 3(6):95 - 103.

10. ICH Guidelines on Analytical Method Validation. In proceedings of the International Conference on Harmonization, Geneva. 1996.

11. Yuri kazakevich, Rosario lobrutto. High Performance liquid Chromatography for Pharmaceutical Scientist: john wiley and sons, Inc., Hoboken New jersy. 2007.

12. Becket AH, Stenlake JB. Practical Pharmaceutical Chemistry. Part -II. 4th edition. CBS Publishers and Distributors: New Delhi. 2007. 